\title{
PRESENÇA TUPI EM TUCUM, MUNICÍPIO DE TANHAÇU, BAHIA: URNA FUNERÁRIA E OUTROS MATERIAIS ARQUEOLÓGICOS.
}

\author{
Carlos Etchevarne ${ }^{\mathrm{i}}$
}

iFFCH/UFBA - Orcid

https://orcid.org/0000-0003-28175788

\begin{abstract}
Resumo: Na Bahia, os grupos Tupi tiveram uma dispersão territorial que abarcou diferentes ambientes naturais. $O$ achado da urna de Tucum, prova que a área do centro sul, que na forma atual corresponde a uma interseção de cerrado com caatinga, também fora ocupada por grupos Tupi. A urna apresenta características morfológicas muito singulares que a tornam exemplar único, pelo menos entre o conjunto de artefatos dos sítios baianos.
\end{abstract}

Palavras-Chave: Arqueologia baiana; Grupos Tupi; Urna funerária

Abstract: The Tupi groups in Bahia had a territorial dispersion that included different natural environments. The finding of the Tucum urn proves that the area of the southern center of Bahia, which in its current form corresponds to an intersection of cerrado and caatinga, was also occupied by Tupi groups. The urn has very unique morphological characteristics that make it a unique example, at least among the set of artifacts from the Bahian sites.

Key Words: Bahian archeology; Tupi Groups; Funeral urn. 
Precedentes e pressupostos que justificaram a ação da retirada de uma urna Tupi, em Tucum, Tanhaçu

Em maio de 2011, o professor Carlos Etchevarne tomou conhecimento, através do arqueólogo da 7a. Superintendência Regional do Iphan, o técnico Alexandre Colpas, em visita ao Laboratório de Arqueologia da Faculdade de Filosofia e Ciências Humanas da Universidade Federal da Bahia, sob a responsabilidade do mencionado professor, da ocorrência da uma urna funerária, que tinha sido achada, no povoado de Tucum, município de Tanhaçu, por ocasião da abertura de uma vala de implantação de muros para um campo de futebol.

Depois de uma visita técnica em Tucum, o técnico Alexandre Colpas contatou-nos para informar sobre o achado e procurar saber sobre o interesse de uma visita ao local e coleta da urna, por parte dos membros do Grupo de Pesquisa Bahia Arqueológica (UFBA/CNPQ), atuante no âmbito do Laboratório de Arqueologia (FFCH/UFBA). Manifestou-se o interesse e a disponibilidade para a retirada da urna e para a realização de todos os procedimentos cabíveis para a conservação dela, se a prefeitura fosse dar as condições financeiras e logísticas para isso.

Assim, depois de inúmeras tentativas de contatos, se conseguiu, tempo depois, uma reunião com o Prefeito de Tanhaçu, realizada no dia 16 de agosto de 2011, no Laboratório de Arqueologia, contando com a presença do arqueólogo do IPHAN. Nela ficamos sabendo com mais detalhes da circunstância do achado e das expectativas da comunidade sobre a urna, razão pela qual foi sugerido ao Prefeito, o planejamento de um espaço expositivo, com todas as normas de segurança que os materiais exigem. Desta maneira, se garantiria que as peças arqueológicas encontradas retornassem às proximidades do sítio de Tucum, depois de terem sido estudadas, documentadas e acondicionadas pela equipe de Arqueologia UFBA.

Nessa reunião, ficou estabelecido o compromisso entre Universidade e Prefeitura, em que a primeira instituição arcaria com os custos de transporte até Tanhaçu e da movimentação na área de Tucum, com uma van, a gasolina e as diárias do motorista para levar alunos das disciplinas arqueológicas, que, sob a direção do coordenador do Bahia Arqueológica e Professor das disciplinas na UFBA, realizariam o trabalho de retirada e de prospecções no local, que forem consideradas necessárias. Ademais, colocaria a disposição o Laboratório, com todos os instrumentos necessários, para que nele seja feita a restauração da urna. Ficou estabelecido ainda que em todas as etapas dos trabalhos, o Grupo de Pesquisa Bahia Arqueológica estaria 
atuando diretamente ou, então, assessorando, sempre sob a forma de colaboração gratuita, à prefeitura de Tanhaçu. Finalmente a viagem foi realizada em fevereiro de 2012.

\section{Generalidades sobre os ambientes natural e social do povoado de Tucum}

O município de Tanhaçu, limita ao norte com Ituaçu, município do extremo sul da Chapada Diamantina, do qual se emancipou há algumas décadas. Pelo ambiente natural pode-se dizer que está encravado no domínio geomorfológico dos granitoides, ou seja, que está inserido na ampla região baiana classificada como "pediplano sertanejo", caracterizada pela ocorrência de um tipo especial de relevo denominado inselberg ou afloramentos residuais, extremamente trabalhados.

Efetivamente, a paisagem predominante corresponde a vastas planícies e serras ou morros de pouca altura, pelo geral arredondados, assim como os solitários afloramentos de granito, que emergem aqui e lá, em meio a grandes extensões planas, que assemelham esculturas monolíticas, muito trabalhadas pela geodinâmica, já que constituem parte das estruturas cristalinas mais antigas do território brasileiro. É a este tipo de estruturas que se denomina de inselberg.

Sobre os solos, resultado da desagregação das rochas graníticas migmáticas, instalou-se, em linhas gerais, a cobertura vegetal do semiárido, ou caatinga com algumas variações de espécies arbóreas do cerrado. Porém Tucum parece gozar de uma situação particular, provavelmente por receber mais precipitações anuais ou por ter solos de transição, que mostram misturas com material sedimentar derivados de arenitos, não muito distantes, como os do Morro da Bucânia, a menos de $15 \mathrm{~km}$ de Tucum, que marca o final da Chapada Diamantina, por sua parte sul (Figura 1).

O aspecto físico da paisagem natural dominante é de colinas baixas e pendentes suaves, com vegetação nativa de pouca altura, mas, nesse período do ano (fevereiro), bastante verde. 0 riacho Tapera, afluente do Rio de Contas, encontra-se a cerca de 150 m do sítio, mas, na época da visita, estava ainda seco. Os barrancos de $3 \mathrm{~m}$ de altura, aproximadamente, demonstram que antigamente o riacho era caudaloso. Neste sentido, vale apontar que há moradores de Tucum que lembram, quando eram crianças, terem pescado nele abundantes peixes da espécie traíra e que tomavam banho durante o ano todo, confirmando, com isso, que o riacho era perene até alguns anos atrás. Ou seja, pode se pensar que a original situação de 
piscosidade do riacho proporcionaria, ao grupo Tupi ali instalado, uma alternativa proteica a mais, durante o ano todo. O leito do riacho, por sua vez, repleto de seixos grandes, era uma fonte importante de matéria prima na utilização para formação de fundo de fogueiras e ainda como base de postes de cabanas. Porém, por sua natureza, aparentam não serem materiais apropriados para a confecção de instrumentos de pedra.

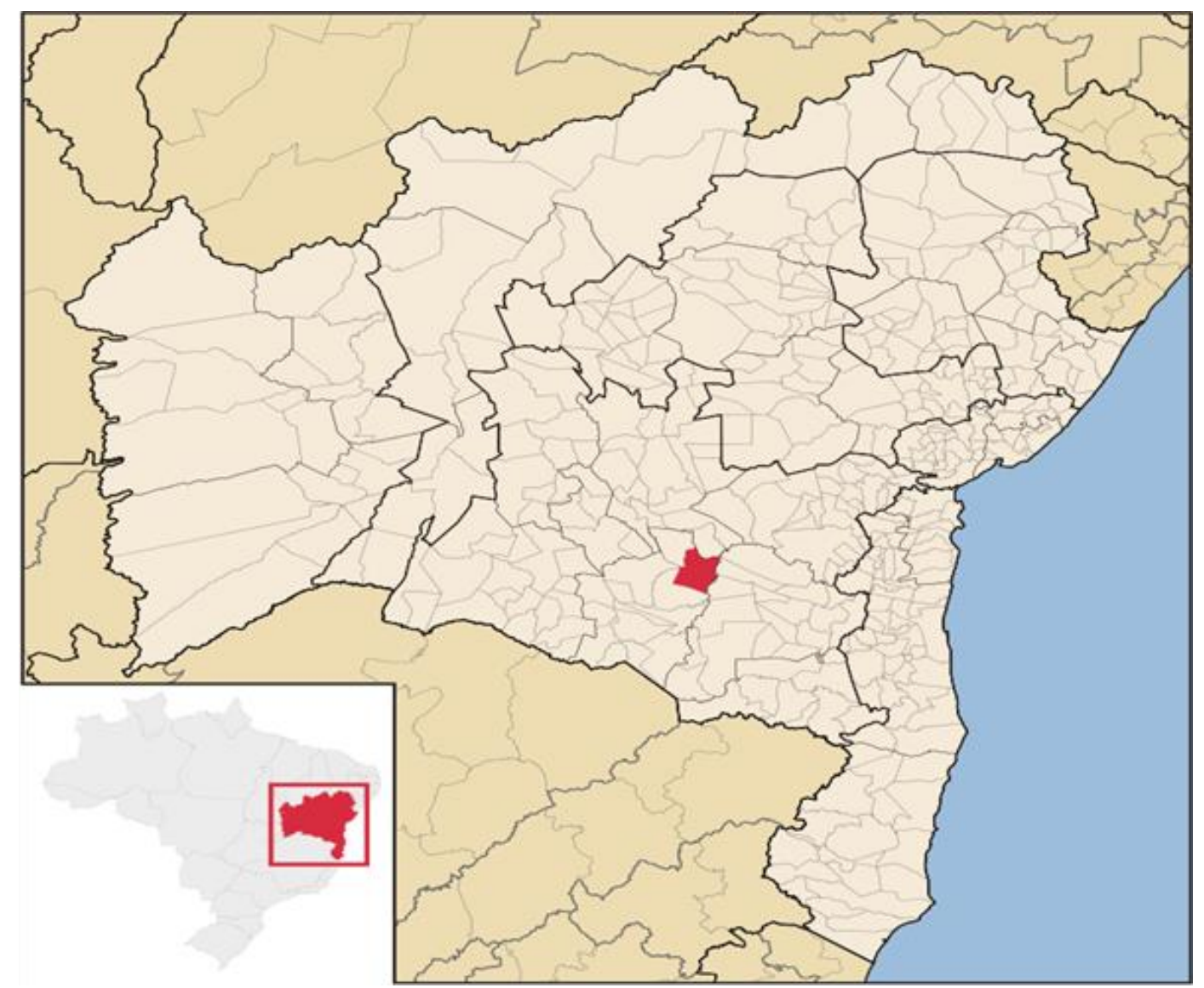

Figura 1: Localização do município de Tanhaçu, distante a $483 \mathrm{~km}$ de Salvador, Bahia e a $250 \mathrm{~km}$ em linha reta de do porto atlântico de llhéus https://pt.wikipedia.org/wiki/Tanha\%C3\%A7u\#/media/Ficheiro:Bahia_Municip_Tanhacu.svg

Entre as espécies nativas que se localizam em torno do povoado sobressaem as da caatinga, como as unha de gato e as palmeiras ouricuri (ou liquiri), juazeiro, jurubeba, tamborim, pauferro, que se misturam a outras do cerrado, de maior porte. Porém são muitas as plantas introduzidas tanto arbustivas como arbóreas que ficaram "naturalizadas" na paisagem, como as carobas, mangueiras, eucaliptos, flamboyants, entre outras.

O povoado está constituído por casas esparsas, conformando um núcleo mais adensado em torno de uma pequena igreja, de arquitetura simples. O prefeito da cidade assinalou que, em 
2012, mais de 85 \% das casas de Tucum têm cisternas, que, por falta de chuvas, eram abastecidas com caminhões pipa, com água tratada pela Embasa, em Tanhaçu. Próximo ao sítio construíram uma igreja evangélica Assembleia de Deus, com materiais industrializados, conformando um espaço amplo e sólido.

Observa-se um padrão construtivo constante nas casas da região, considerado como exemplo de arquitetura vernacular: um corpo único, com paredes construídas em pau a pique ou com adobes, devidamente rebocadas com barro e caiadas, teto de telhas, com duas águas dispostas paralelas à rua. Nas fachadas observa-se uma regularidade na colocação das portas e das janelas (uma ou duas), todas bem alinhadas pela parte superior da abertura. Tanto umas como outras são de madeira e as janelas não possuem vidro.

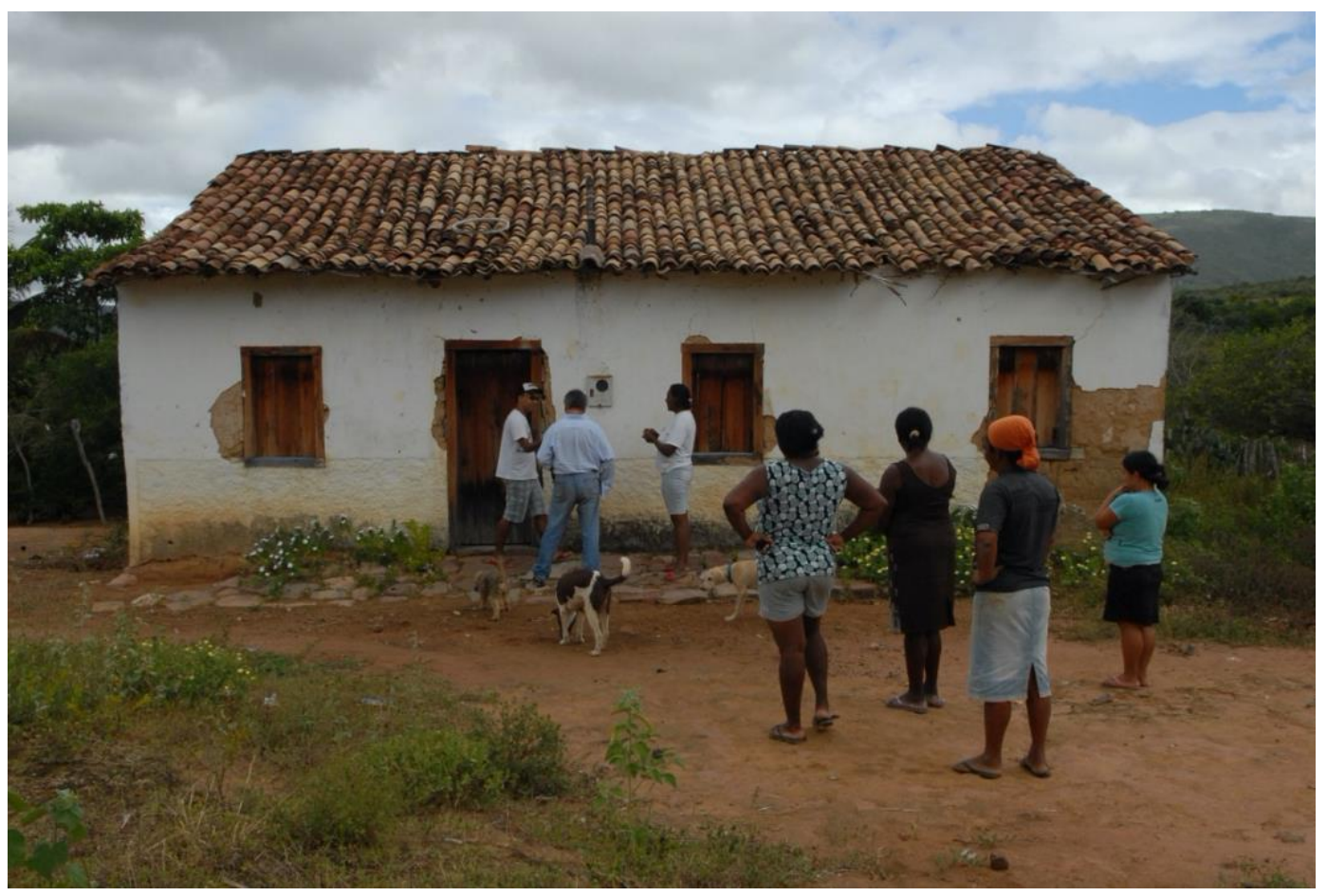

Figura 2: Tucum. Exemplo de casas de arquitetura vernacular, da região de Tanhaçu.

Atualmente, em função do programa do governo federal Água para Todos, a maioria das casas tem uma calha de alumínio beirando os tetos, que serve para a coleta de água de chuva, transportando-a até uma cisterna, situada ao lado ou nos fundos das casas. Em função desses dispositivos, os moradores de Tucum têm suprido suas necessidades básicas.

O aspecto geral das residências é de grande higiene e de um cuidadoso sentido estético, que persegue a harmonia do conjunto do povoado. Na maioria das casas há árvores e plantas com 
flores na parte externa ao longo da fachada, proporcionando um aspecto visual muito agradável e acolhedor.

Infelizmente, a Funasa está mudando esse padrão de arquitetura, porque as casas são de pau a pique e podem abrigar barbeiros (Trypanosoma cruzi), insetos transmissores do mal de Chagas. Como o novo padrão arquitetônico (tipo chalezinho), construído em blocos de tijolos ocos industrializados e cimento, com divisões internas não tradicionais, está projetado por técnicos de órgão públicos, em Brasília, se desconhece a importância da arquitetura vernacular (que poderia muito bem ser adaptada às condições de salubridade). Esta situação acarreta o abandono ou a destruição de casas antigas, fato anunciador que em pouco tempo se deixará de construir à maneira tradicional e não se conservará nenhum exemplar de arquitetura vernacular.

No povoado de Tucum existe uma situação social particular. Recentemente foi declarado como população descendentes de escravizados quilombolas, ou seja, remanescente de antigos quilombos. Porém os moradores afrodescendentes convivem com os de origem europeia em uma aparente mistura espacial (questão que deveria ser confirmada, com um estudo de campo mais aprofundado). Tem ainda pessoas com traços faciais que se aproximariam aos indígenas, mas que não se definem etnicamente assim. Por outro lado, são todos pequenos proprietários de sítios e até onde podemos saber, não há terras comuns.

Existe um vereador e presidente da Associação Quilombola de Tucum, Sr. Carlitos Augusto Oliveira, que lutou, politicamente, para o reconhecimento de Tucum como remanescente de quilombo por parte da Fundação Palmares. Porém, atualmente sua liderança política, dentro da comunidade de Tucum, está sendo contestada, inclusive por parte de população reconhecida como negra. Pelo que foi possível averiguar, os desconformes não acharam vantagem prática nenhuma no reconhecimento como população quilombola. Deve ser considerado também que o vereador é oposição ao prefeito, fato que sem dúvida traz desvantagem na friç̧ão entre ambos e, pode ter provocado o desgaste da imagem pública do vereador.

\section{Atividades realizadas em Tucum}

Como parece obvio deduzir, a principal atividade realizada pela equipe de pesquisa, no povoado de Tucum, foi a retirada da urna funerária, motivo específico da viagem. A urna 
encontrava-se semi-descoberta, a cerca de $60 \mathrm{~cm}$ da superfície. Ficou posicionada em um dos extremos de uma área aproximadamente retangular, no traçado de uma linha reta formada por uma das valas, destinada aos alicerces de um muro que formaria parte de uma quadra poliesportiva. Alguns operários que trabalhavam nessa empreitada encontraram a urna, quebrando-a em várias partes, primeiro em função de não saber da sua existência no sub-solo, e, depois, como é frequente acontecer, pela curiosidade em conhecer o seu conteúdo.

Não obstante esta circunstância fortuita, quase todos os fragmentos foram encontrados, salvo uma parte de um grande assador, usado como tampa, que, conforme a esposa do prefeito, teria sido entregue, por ela mesma, a uma pessoa da equipe de arqueólogos que trabalhava, no momento da descoberta, na região sul do município de Tanhaçu, realizando prospecções de arqueologia preventiva, como medida exigida por lei, na área do projeto de instalação da Ferrovia Leste Oeste.

A primeira medida consistiu em retirar as madeiras velhas e tecidos de arame que tinham sido colocados, pelos moradores vizinhos, como forma de proteção do poço da urna, e, ainda, começar a coletar dos restos cerâmicos que estavam soltos. Depois, limpou-se a área em torno e procedeu-se a rebaixar o solo em uma distância que variou entre $50 \mathrm{~cm}$ e $80 \mathrm{~cm}$ afastandose da urna, para que fosse possível retirar os fragmentos pela parte externa. Esse procedimento serviria, caso estivesse inteira, para poder suspende-la com maior facilidade.

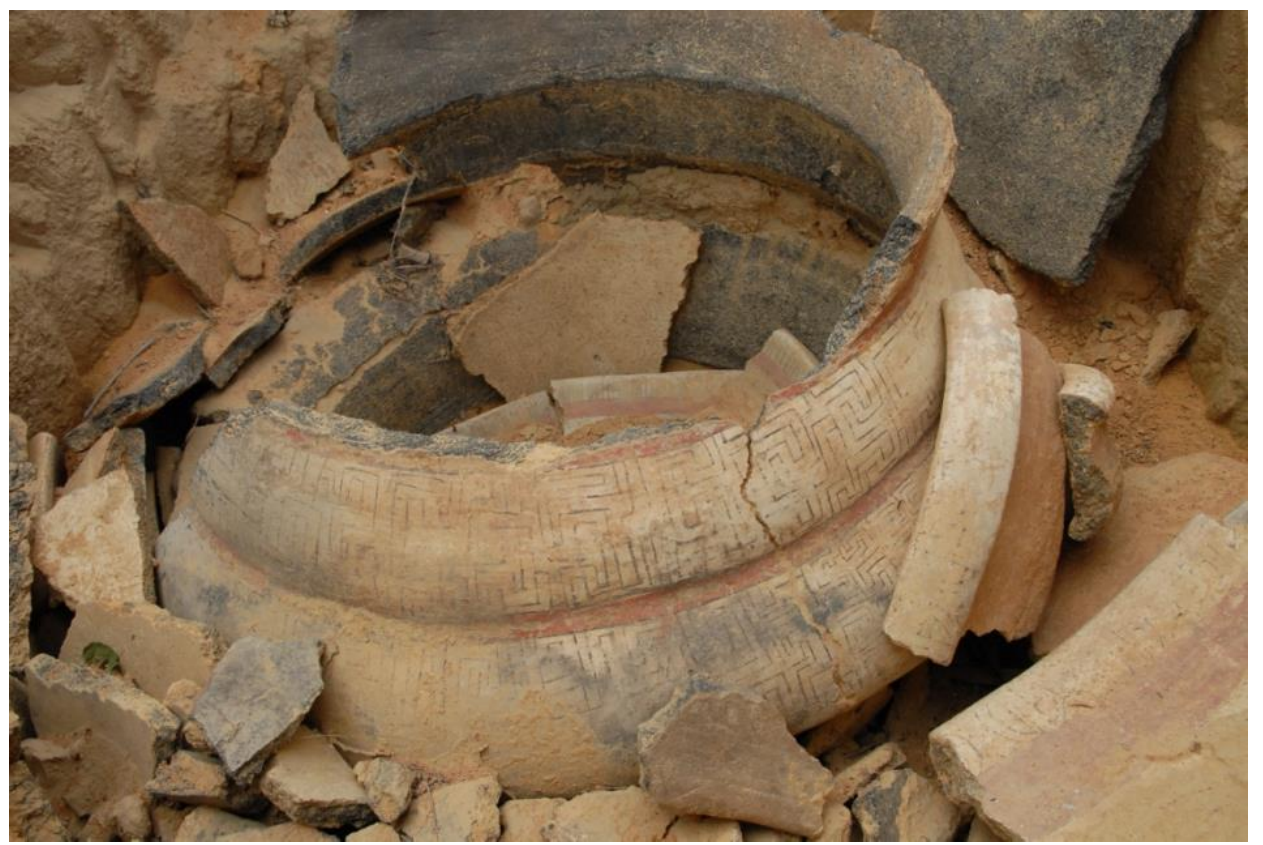

Figura 3: Tucum. Estado de fragmentação em que se encontrava a urna, à chegada da equipe de Arqueologia da UFBA. Foto Carlos Etchevarne. 


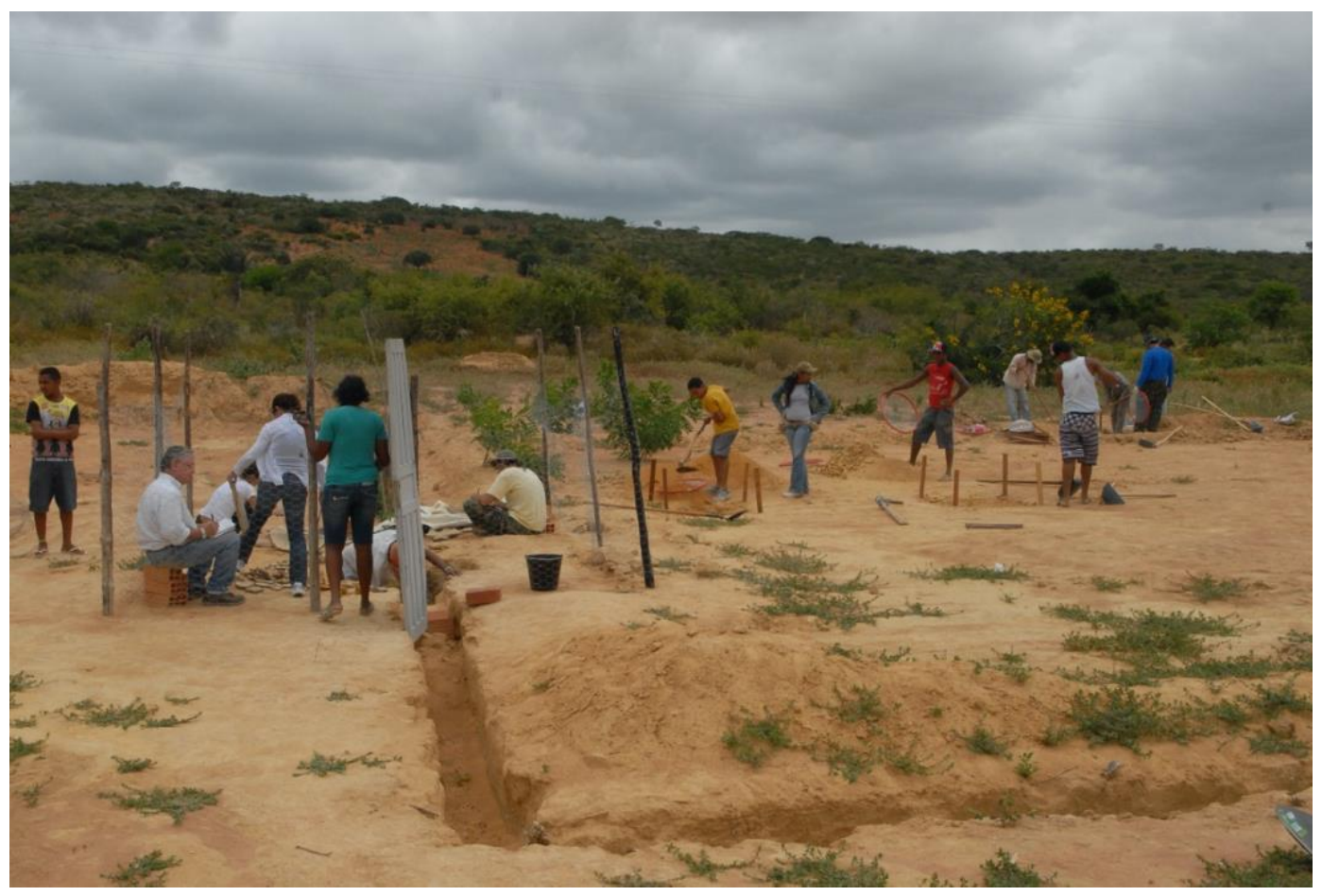

Figura 4: Tucum, vista geral sobre a área do achado da urna, que foi cercada pelos moradores para evitar perturbações. Observe-se, em primeiro plano, a valeta para alicerces do muro que deveria limitar o campo poliesportivo. Na linha da valeta foi encontrada a urna. Foto: Nei Costa

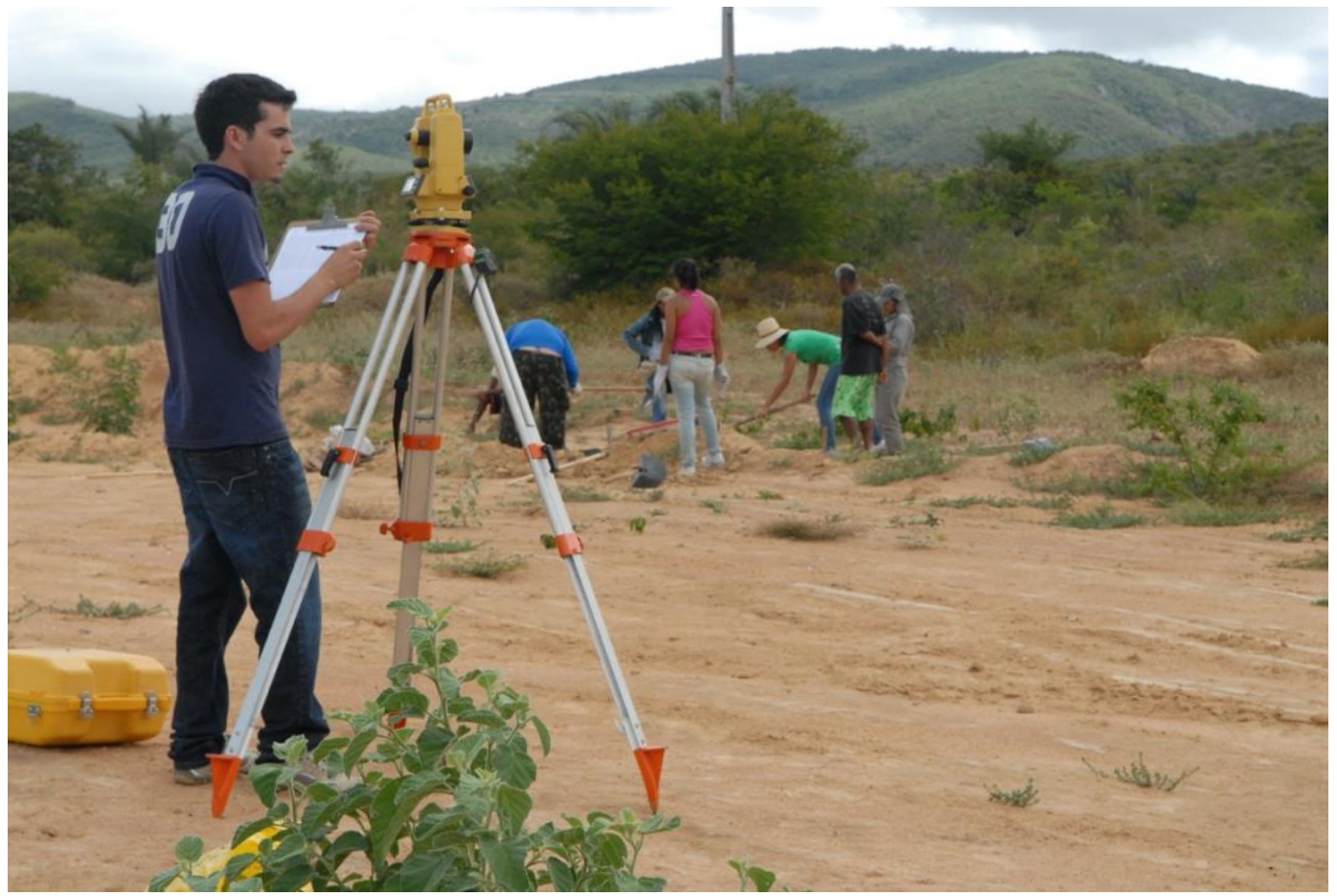

Figura 5: Tucum. Topógrafo localizando as ocorrências de vestígios cerâmicos em superfície para plotar em uma planta da área. Foto Carlos Etchevarne 


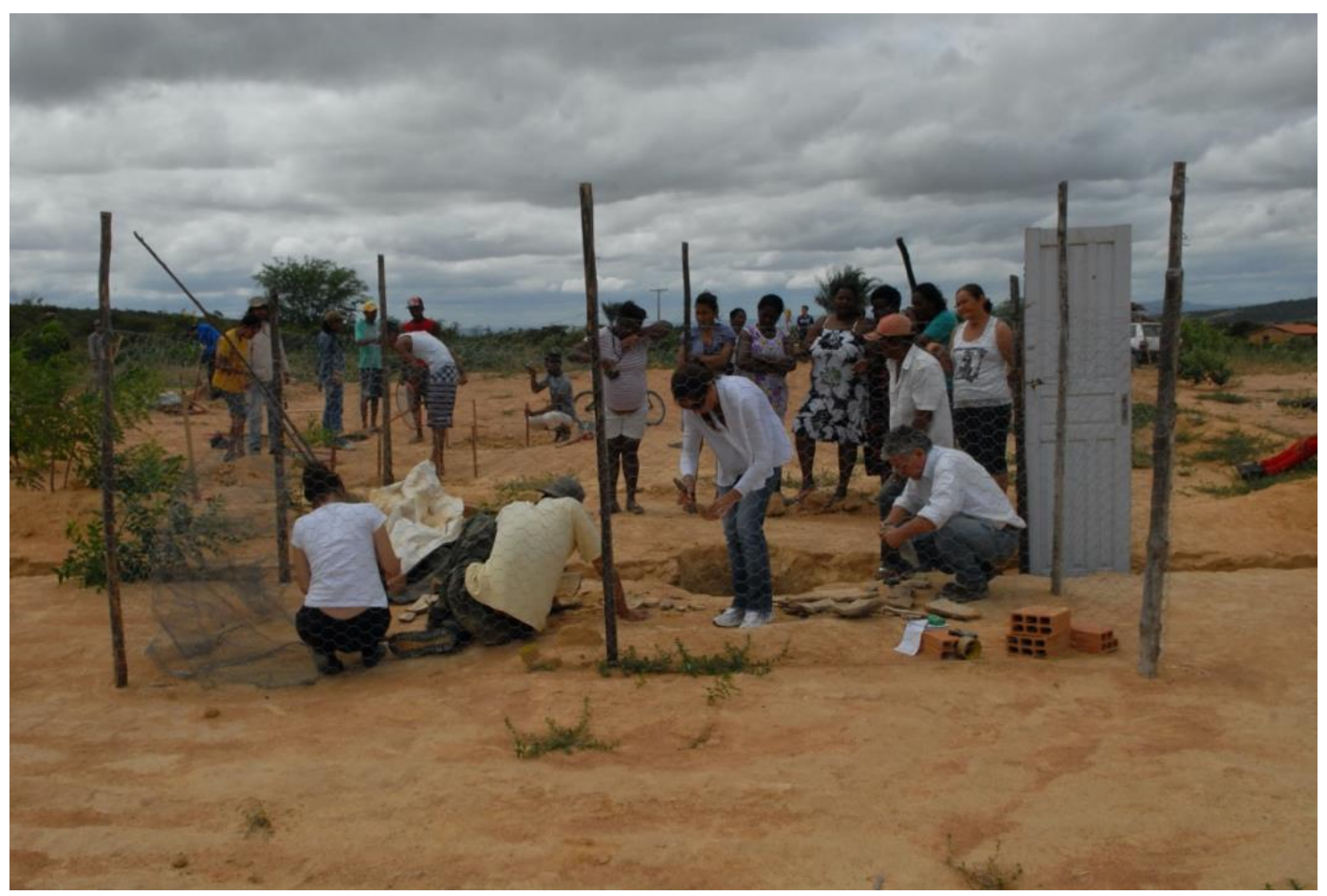

Figura 6: Tucum. Membros da equipe de Arqueologia e moradores que foram convidados a observar e participar da retirada da urna. Foto Nei Costa.

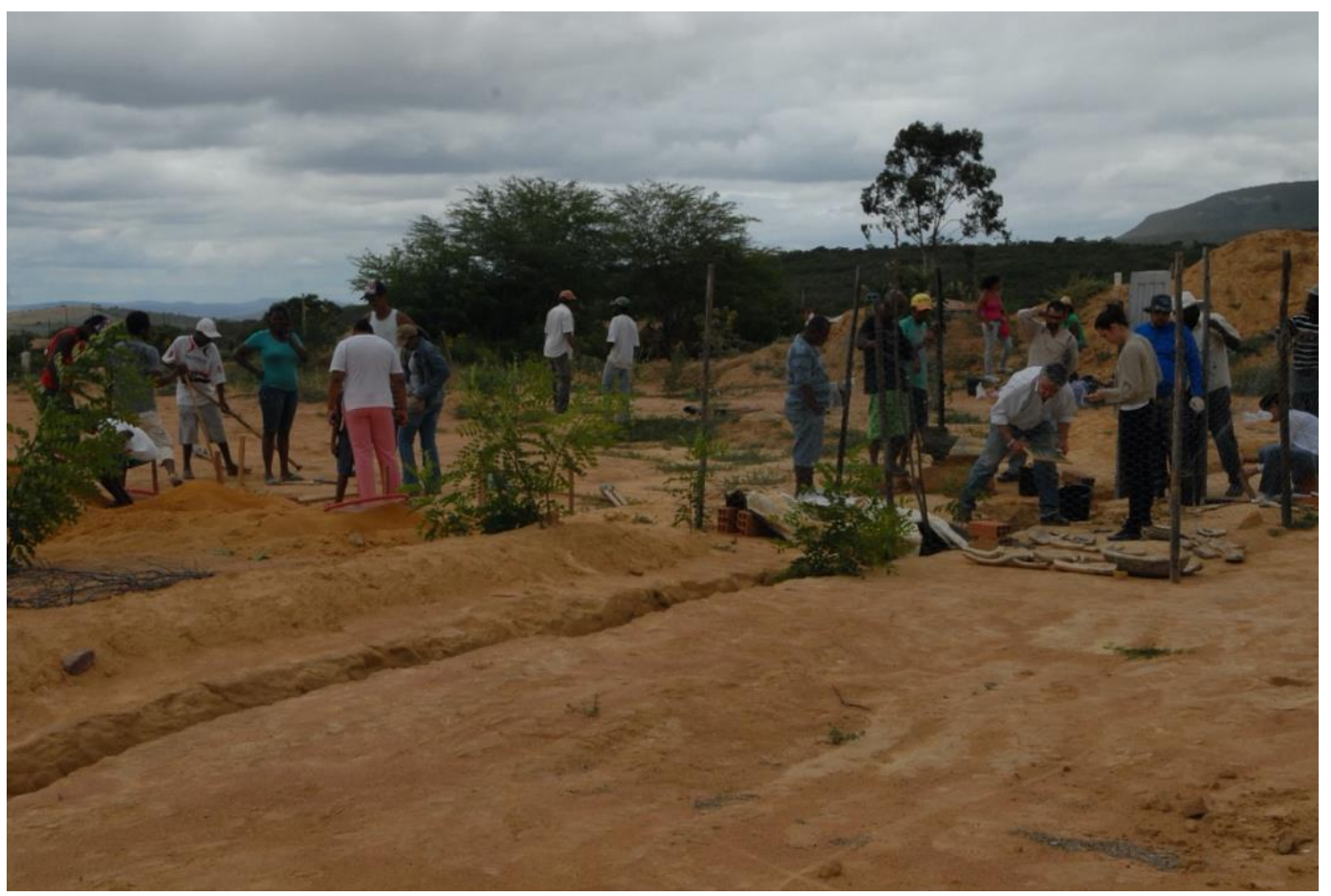

Figura 7: Tucum. Participação de membros da comunidade na retirada da urna, na localização de material em superfície e nas sondagens de prospecções que foram abertas. Foto Nei Costa 


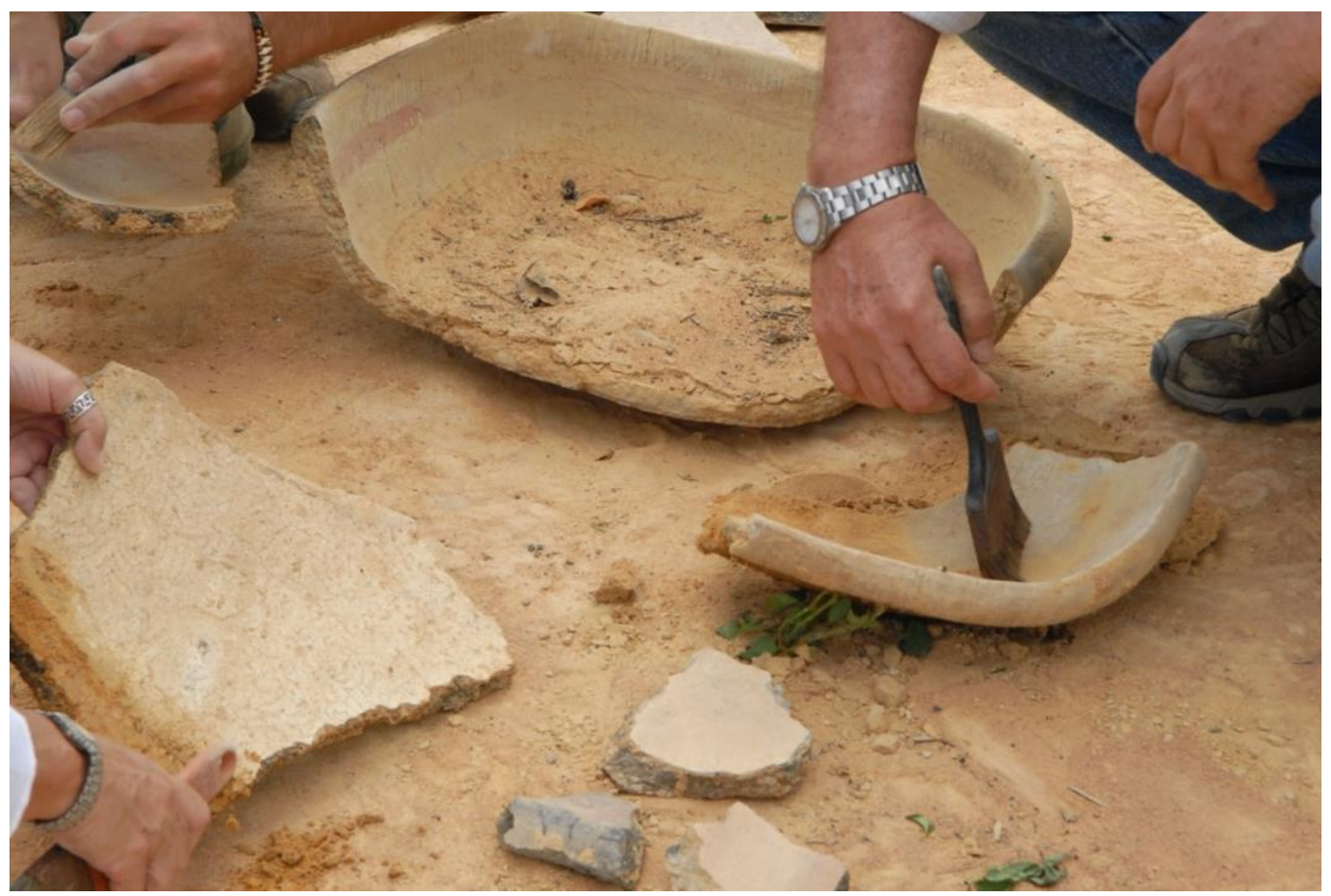

Figura 8: Tucum. Retirada, com pincel, de sedimentos aderidos aos fragmentos cerâmicos. Foto Foto Nei Costa

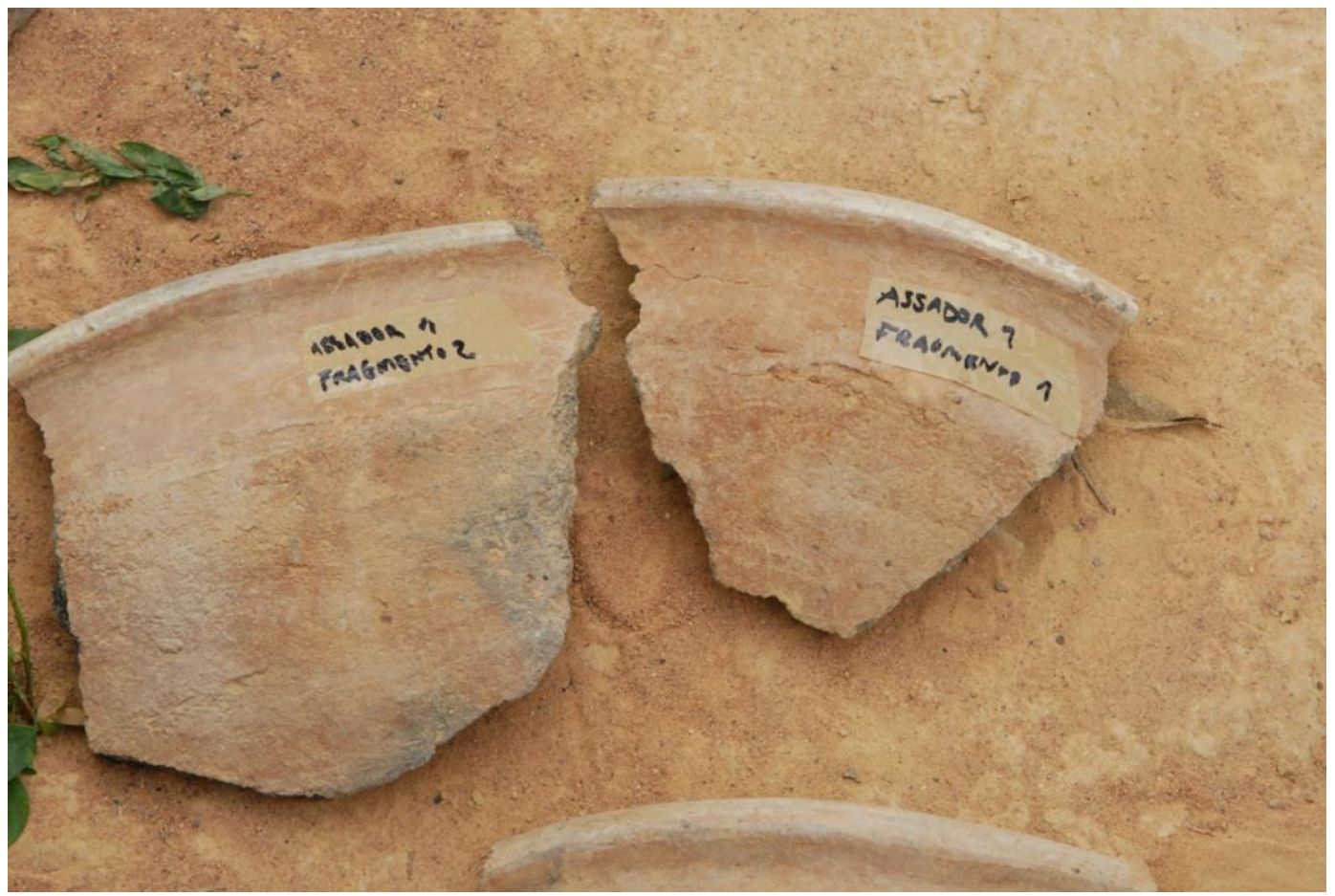

Figura 9: Tucum. Fragmentos de assador, numerados segundo a posição que ocupavam na hora da retirada, com aplicação de fitas aderentes e marcador. Foto Carlos Etchevarne 


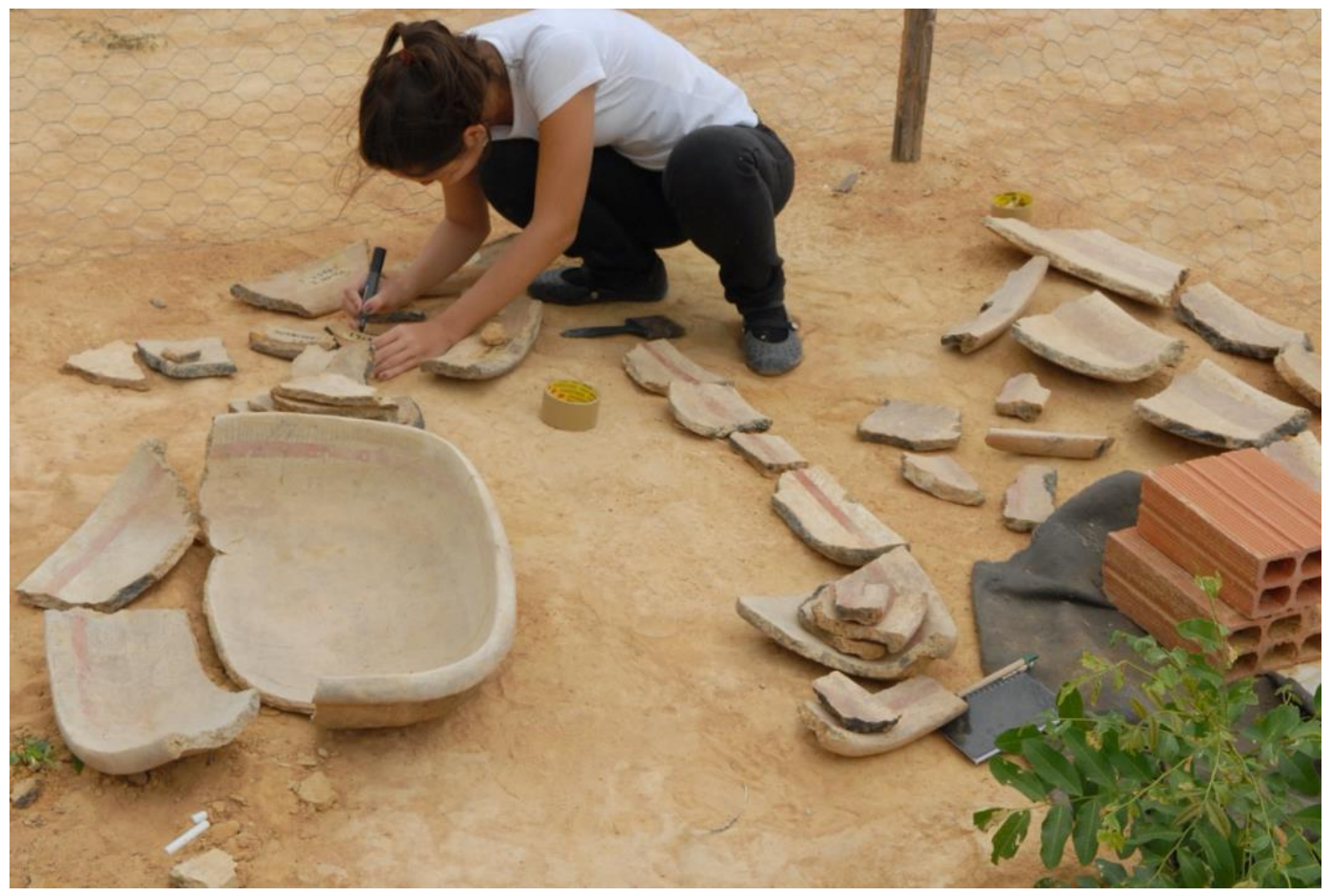

Figura 10: Tucum. Registro e classificação de materiais in situ. Em primeiro plano, assador que se encontrava dentro da urna. Foto Carlos Etchevarne

Dessa maneira, aprofundou-se o solo até $1,50 \mathrm{~cm}$ e assim, se chegou à base da urna, onde se encontraram grandes fragmentos, com decoração diferente, demonstrando claramente não pertencerem nem ao invólucro funerário nem ao opérculo. Esses fragmentos irregulares e desiguais, que correspondem a partes do bojo de um contentor de líquido e de um assador, apresentam, o primeiro, decoração incisa e, o outro, pintada. Estes teriam sido colocados, uma vez aberto o poço, de forma ligeiramente inclinada, provavelmente com a intenção de fixar a urna em posição vertical, escorando-a, até esta ser coberta pela terra que a cobriria completamente. Aqui vale lembrar que a base da urna era conoidal, ligeiramente arredondada.

O pacote funerário stricto sensu estava composto por três recipientes cerâmicos: o invólucro ou a urna propriamente dita, uma tampa formada por um assador de grandes dimensões e um acompanhamento, colocado internamente junto ao corpo, composto por outro assador menor. Ambos os assadores correspondem morfologicamente àqueles típicos dos grupos Tupi arqueológicos, ou seja, são quadrangulares, com vértices arredondados, bordas com reforço espesso, de perfil triangular. O material ósseo que nos foi apresentado pelos moradores era 
parte de um fêmur, mas não conseguimos saber, com certeza, se havia mais ossos de outras partes do corpo ${ }^{1}$.

Por sua vez, os elementos decorativos são pintados, em fundo branco ou creme, linhas escuras (pretas ou pardas) e faixas horizontais vermelhas. Os motivos pintados estão diferenciados por áreas funcionais do recipiente, sendo as bordas pintadas imitando as cestas de fibras e o interior do recipiente com elaborados elementos curvilíneos chamados, pela sua aparência, de "filigranas" ou "rendados".

Tomando como ponto central a urna, foram realizados poços sondagens, como o objetivo de verificar se em sub superfície se encontravam outros recipientes funerários ou qualquer outro vestígio. Assim, foram realizados mais cinco poços de $1 \times 1 \mathrm{~m}$ aprofundando-se até $1,80 \mathrm{~m}$ da superfície, seguindo em linha reta para o sul. Na parte central de um dos lados do retângulo (que seria a quadra poliesportiva), abriu-se uma sondagem de $2 \times 1 \mathrm{~m}$, posto que apareciam pequenos fragmentos em superfície que poderiam estar assinalando continuidade dos materiais no sub solo, fato que não foi confirmado.

Outras quinze sondagens foram realizadas em alguns pontos onde apareciam fragmentos cerâmicos superficiais, seja na área onde seria uma quadra, seja nas proximidades em direção ao riacho Tapera. Os sedimentos imediatamente embaixo dos $15 \mathrm{~cm}$ estavam muito compactados, difíceis de serem removidos. No $1 \mathrm{~m}$ de profundidade escavado, não apareceram indícios de alteração na coloração ou na granulometria do solo. Cabe ressaltar que em nenhuma das sondagens foi encontrado material arqueológico, o que de certa maneira era de se esperar, levando em conta que:

a) a área foi utilizada como roça por tempo indefinido e por isso os materiais que poderiam ter ficado foram deslocados ou destruídos pela população contemporânea;

b) em função da destruição do solo de habitação, fica impossível reconhecer qual poderia ser o perímetro da área que a aldeia ocupava, com outros prováveis sepultamentos.

\footnotetext{
${ }^{1}$ Segundo os moradores, desde a descoberta da runa até a chegada da equipe de arqueologia da UFBA, se passaram mais de 30 dias, lapso de tempo em que houve alguns incidentes, como tentativa de tirar de vez, briga de cachorros dentro do buraco da urna, entre outros.
} 
Aqui se tornaria necessário realizar uma série de prospecções com GPR. Elas poderiam auxiliar, consideravelmente, a tarefa de identificação de enterramentos, sem necessidade de abrir rede de sondagens, que por mais sistemáticas que elas sejam, podem não resultar em achados.

Convém apontar que a urna funerária tem alguns traços morfológicos e decorativos que a particularizam. A parte superior do bojo tem uma composição de formas superpostas, com presença de duas carenas separadas por uma faixa de corpo do bojo. A parte inferior, desde onde se realiza a inflexão da direção das paredes, não foi decorada, seguindo, neste sentido, o modelo tradicional Tupi. Em uma das partes aneladas há uma faixa avermelhada, com figuras ovais da cor da avermelhada. Esta forma de decoração é inusitada, pelo menos para os contextos arqueológicos baianos dos grupos indígenas pré-coloniais, sejam eles Tupi ou não. Em oposição, os dois assadores correspondem, como disséramos acima, aos modelos convencionais deste tipo de recipientes associados a esses grupos.

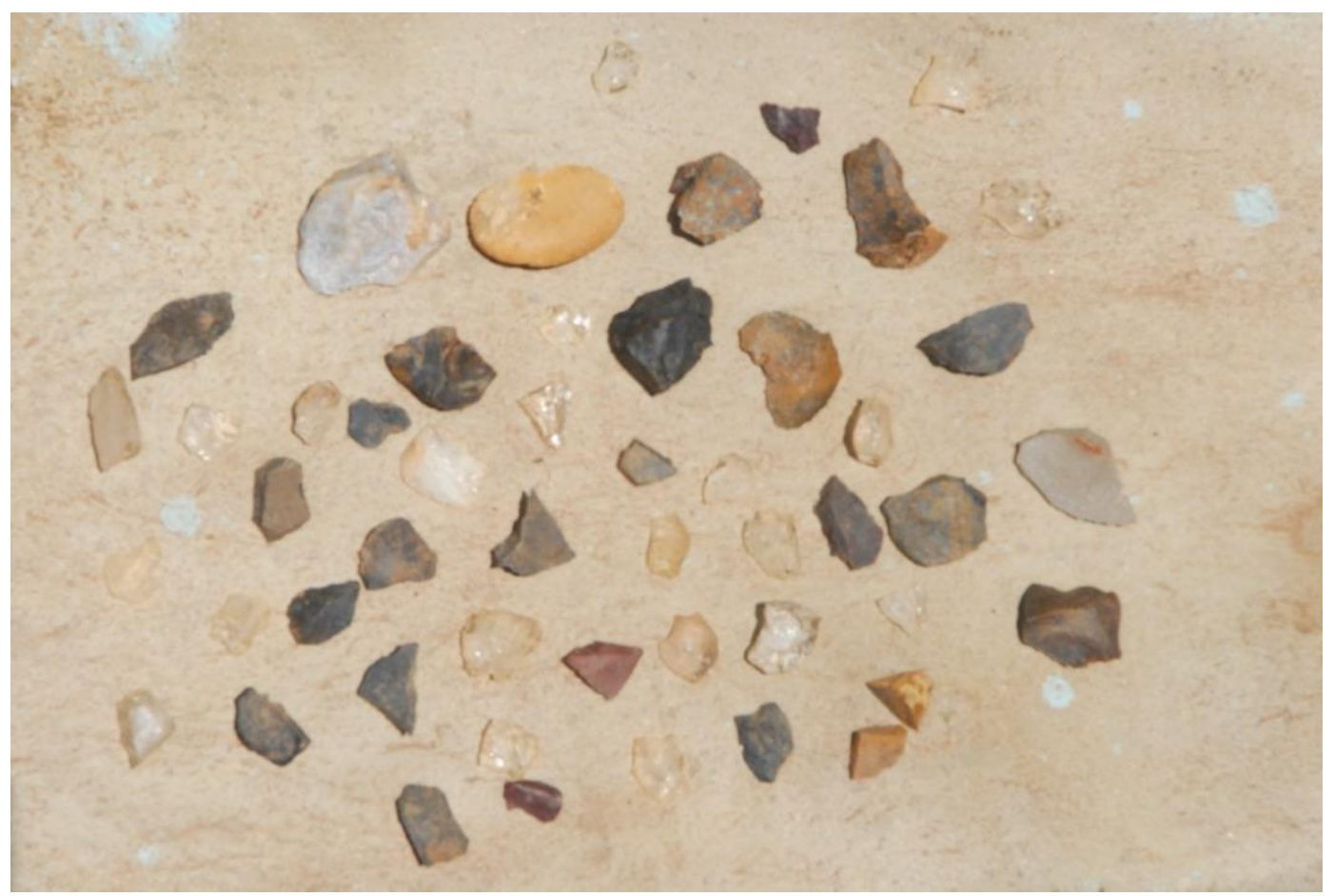

Figura 11: Tucum. Material lítico, encontrado espalhado em superfície em áreas próximas ao local da urna. São lascas retocadas e seixos de quartzo leitoso, com sinais de percussão ou, então, marcas de retiradas de lascas.

Atividades de socialização de informações arqueológicas e contatos com os moradores locais

As atividades de coleta de material arqueológico, provocou grande curiosidade entre os moradores do povoado de Tucum, que se reuniram rapidamente à chegada da equipe de 
pesquisadores e ficaram acompanhando todo o processo de retirada da urna, de abertura de sondagens e de coleta de fragmentos cerâmicos em superfície. Esta proximidade entre equipe e moradores permitiu que se estabelecesse grande interlocução e pudessem ser transmitidos, informalmente, boa quantidade de informações arqueológicas, usando o próprio sítio como exemplo didático. Aqui, cabe ressaltar que os alunos que participaram da viagem e que cursam as disciplinas arqueológicas tiveram um papel muito importante, demonstrando uma grande disposição com o trabalho e forte empatia com o lugar e as pessoas.

Outras atividades de educação patrimonial foram realizadas durante a permanência da equipe, com caráter mais formal. A primeira delas foi no próprio povoado de Tucum, no espaço cedido pela igreja Assembleia de Deus, que tinha equipamentos eletrônicos, como microfone e data show, que facilitaram as exposições realizadas por vários membros da equipe de arqueologia. Neste evento estavam presentes mais de 120 pessoas, contando ainda com presença do prefeito de Tanhaçu e a do secretário de Planejamento.

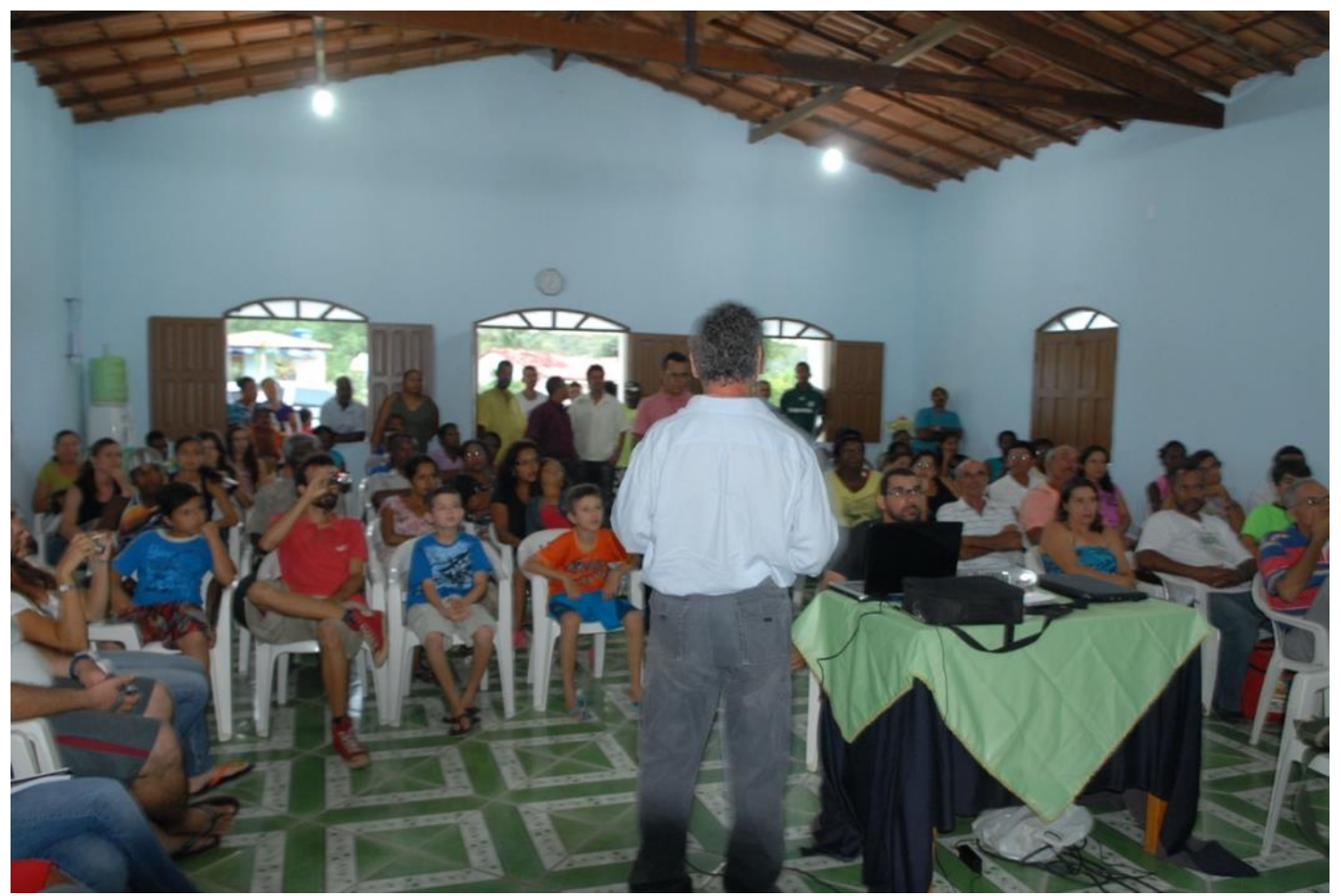

Figura 12: Tucum. Interior da igreja Assembleia de Deus, com membros da comunidade e representantes da prefeitura de Tanhaçu, para apresentar o trabalho realizado pela equipe e dirimir dúvidas sobre procedimentos, preservação e destino da urna. Foto Nei Costa

A reunião teve uma duração mínima de $2 \mathrm{~h}$, tempo suficiente para se falar sobre pontos básicos de arqueologia em geral e sobre os grupos Tupi em particular. Usando-se como elementos didáticos power points preparados pela equipe de pesquisadores, que ajudaram a compreender melhor a vasta gama de repertórios arqueológicos encontrados no Brasil e, mais 
especificamente, na Bahia. Houve também participação da comunidade com perguntas gerais sobre a prática arqueológica e sobretudo sobre o destino dos materiais arqueológicos, já que era reivindicado a permanência dos objetos na localidade. O prefeito se comprometeu publicamente, frente a esse auditório a construir um pequeno espaço museal, onde pudessem ser colocados e protegidos, depois de terminado o processo de restauração. Todos, comunidade, equipe de pesquisadores e alunos saudaram com muita alegria essa iniciativa.

A segunda reunião teve que ser convocada duas vezes, porque houve desentendimentos políticos entre as pessoas que a convocaram. A reunião foi levada a cabo na Casa de Câmara de Vereadores, na cidade de Tanhaçu, com participação de vários edis e moradores da cidade. Igualmente, foram usadas imagens projetadas com os mesmos power point mostrados em Tucum e foram respondidas muitas perguntas, de caráter arqueológico e histórico, mas também de cunho político, como a instituição que ficava com a guarda, os recursos que seriam destinados para a construção do prédio e por que ele devia ser feito em Tucum e não em Tanhaçu, o uso propagandístico que poderia ser dado à construção do espaço museal por parte dos agentes da administração municipal, etc. Estes questionamentos provam, mais uma vez, que a pesquisa arqueológica, não pode estar dissociada da realidade social onde é realizada e, muitas vezes é condicionada por interesses alheios aos interesses arqueológicos.

Considerações gerais sobre os grupos Tupi na Bahia, segundo os dados proporcionados por pesquisas sistemáticas e outras intervenções

Sob a tradicional denominação Tupi, englobam-se, em Arqueologia brasileira, os sítios arqueológicos de grupos que compartilhavam alguns elementos da cultura material, especialmente a os artefatos de produção cerâmica. De fato, é através desses vestígios que foi construída uma macro unidade cultural Tupi que se aplica a todas as situações arqueológicas onde ela é reconhecida, não importando os ambientes naturais onde se encontram. Na Bahia, os grupos Tupi tiveram continuidade histórica até o período de colonização, sendo os primeiros, mas provavelmente não os únicos, a serem contatados pelos portugueses na área litorânea, sobrevivendo ao impacto da conquista e colonização, sob a forma de grupos aldeados pelos missionários jesuíticos (Albuquerque, 2008 e 2009; Etchevarne, 2009 e 2020; Martin, 1996; Oliveira, 2009). 
Na Bahia, as localidades com materiais de origem Tupi, sejam eles pré-coloniais ou coloniais, ocorrem em todas as regiões, desde o litoral, com ambientes de mata atlântica, até o cerrado, no oeste do estado, incluindo as serras e chapadas no centro, assim como os vales de rios que atravessam o semiárido da caatinga baiana.

Através de uma visita nos arredores de Tucum, se constatou que muitos moradores apontavam locais com material arqueológico cerâmico, em um rádio de aproximadamente 1 $\mathrm{km}$ do ponto onde se encontrou a urna. Houve também depoimentos de moradoras, com residências vizinhas ao local do enterramento, que lembram terem brincado, quando crianças, com potes que apareciam na superfície das pequenas roças, contiguas às casas. Essas declarações, tão nítidas na memória das informantes, apontam para uma definição da extensão da superfície da aldeia Tupi, à qual o sepultamento em urna pertencia.

A ampla e variada distribuição territorial de ocorrências de sítios com materiais Tupi, na Bahia, permite pensar em uma diversidade de assentamentos que refletiriam, sem dúvida, diferentes circunstâncias sociais, demográficas, econômicas e até aspectos simbólicos, relativos aos próprios grupos Tupi, assim como os resultados da vinculação desses com outros, nos processos de dominação e consequente imposição cultural que promoveram, quando se deslocavam.

Não obstante, o que fica registrado arqueologicamente é que, na sua maioria, eram grupos que alcançavam números demográficos importantes, foram construtores de aldeias de grande porte, alcançando mais de $300 \mathrm{~m}$ de diâmetro, que eram cultivadores especialmente da mandioca da qual eram grandes consumidores, conheciam a tecnologia do polimento para a produção de instrumentos líticos e tinham práticas funerárias que incluíam, o enterramento primário em urnas, como o caso de Tucum, mas podendo existir outras modalidades.

No que se refere aos objetos cerâmicos há traços tecnológicos que os tornam reconhecíveis rapidamente. Apesar das formas dos recipientes serem variadas, apresentam uma carena que marca a inflexão da direção das paredes dos bojos. As bordas são reforçadas e no corte transversal delas observa-se um perfil quase triangular, traço bem típico. Os recipientes mais característicos são aqueles destinados à conservação de líquidos e a preparação do cauim (bebida derivada da fermentação da mandioca), e os assadores, vasilhames largos e chatos, destinados à queima do bolo da mandioca para eliminar a toxicidade por cocção e para a preparação do beiju. 
Com relação à decoração cerâmica dos grupos Tupi, a pintura sobressai proporcionalmente pela frequência em que aparece em cada sítio e pela elaborada organização de motivos gráficos. Predomina a policromia, baseada no uso do branco-creme para o fundo, e o vermelho e o preto para o delineamento das figuras. Destacam-se os traços muito finos para as composições orgânicas, de elementos serpentiformes e circunvoluções padronizadas, decorando os fundos dos assadores, que permitem compará-las a verdadeiros "rendados" ou, então a "filigranas". A pintura externa da parte superior dos vasilhames contentores de líquidos é executada com traços mais largos e formam composições de linhas retas, paralelas, entrecruzadas, em grecas, etc. Esses dois tipos de motivos de pinturas, os geométricos e as circunvoluções orgânicas, são exclusivos para cada recipiente, sem exceção.

Outras técnicas decorativas na cerâmica Tupi são classificadas como plásticas, ou seja, representam algum tipo de alteração na superfície do recipiente, sem aplicação de pigmentos. Nesta categoria encontram-se as incisões (em linhas contínuas, tracejadas, pontuadas, os campos ungulados), os apliques modelados (especialmente nas bordas) e os corrugados. Esses últimos se realizam aproveitamento os roletes de confecção do bojo, pressionando para a junção deles, de tal forma que se produzem ondulações rítmicas na superfície. Os corrugados podem ser classificados sejam realizados com os próprios dedos (digitados simples) ou com ajuda de um instrumento plano (espatulados), ambos muito recorrentes na cerâmica dos sítios Tupi.

Por todo o exposto acima, a clara distinção e consequente classificação dos tipos cerâmicos arqueológicos pré-coloniais permitiu que o sítio do povoado de Tucum, no município de Tanhaçu, no centro sul da Bahia possa ser filiado, sem nenhuma reserva, aos grupos Tupi. Isto permitiu que ele seja incluído na área de dispersão dos sítios já mapeada e, portanto, ampliados os limites do domínio territorial desses grupos. 


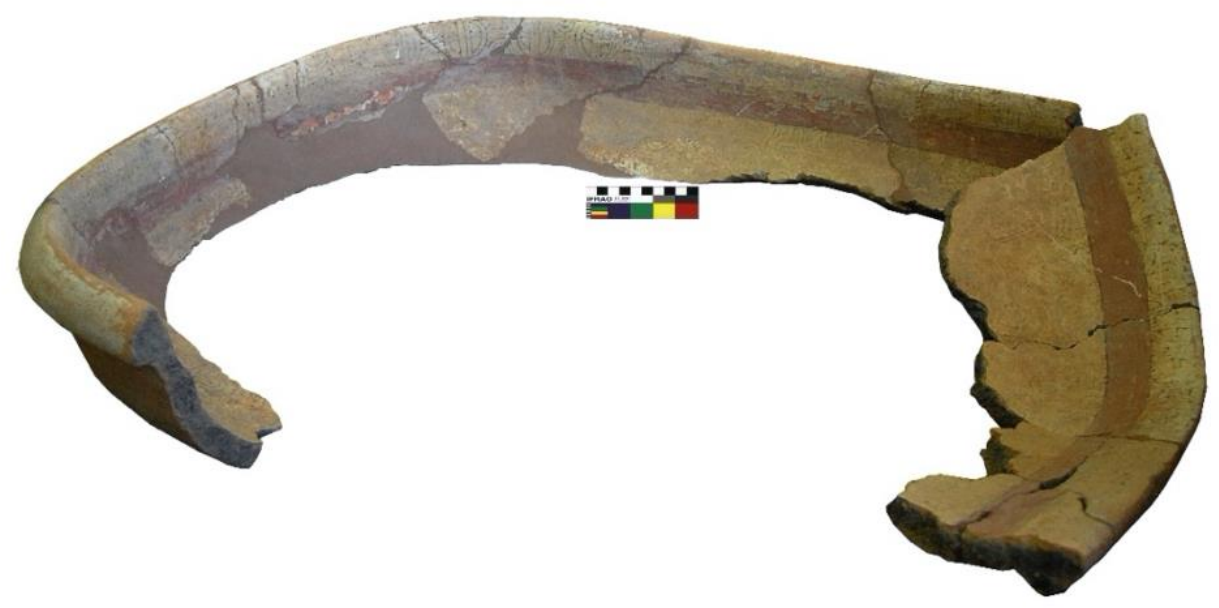

Figura 13: Tucum. Fragmentos do assador maior, usado como opérculo da urna, com as partes que se encaixavam coladas. A parte central da peça, ainda inteira, foi entregue pela esposa do prefeito, antes da chegada da equipe da UFBA, a pesquisadores que realizavam prospecções de arqueologia preventiva, na ferrovia Leste Oeste.

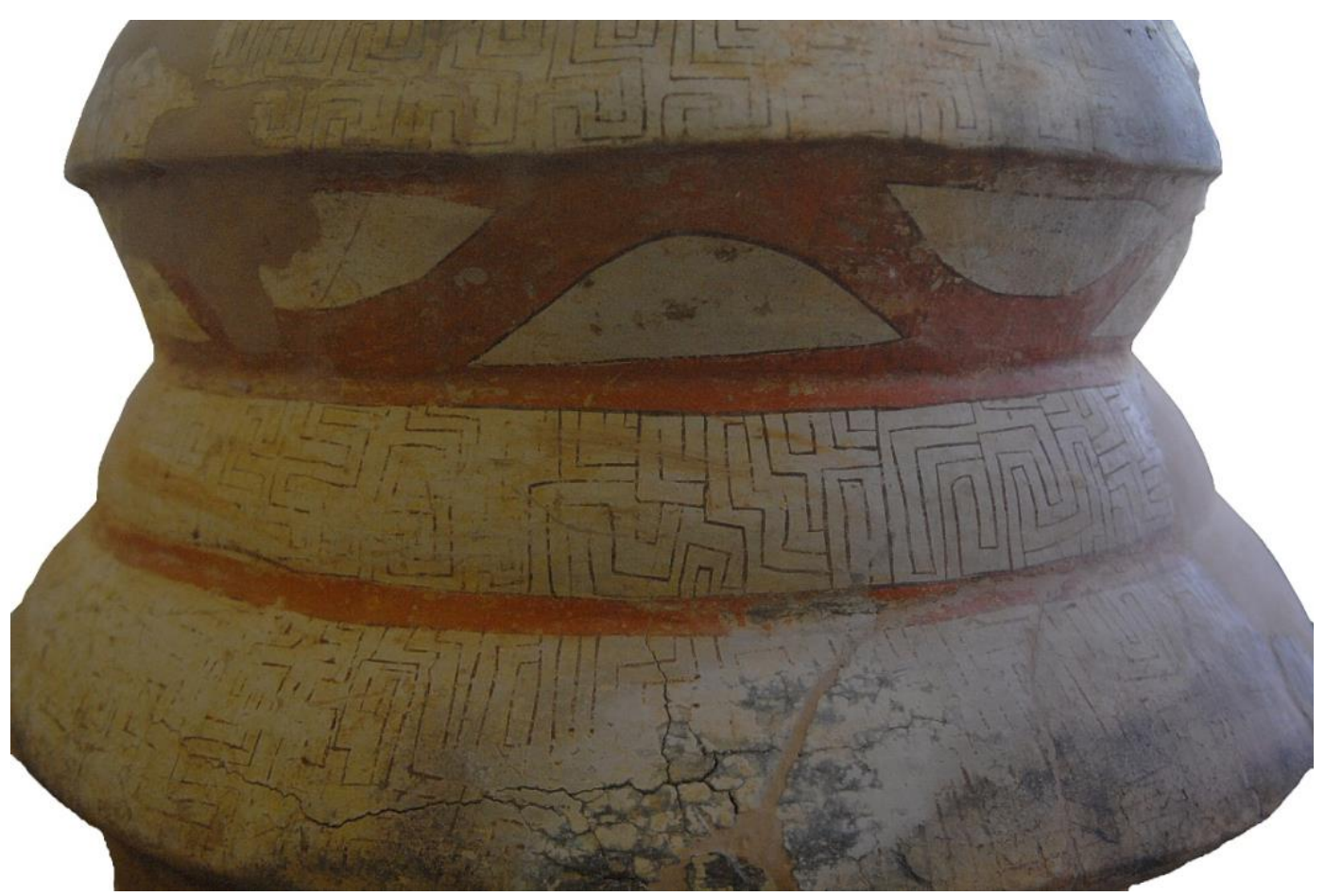

Figura 14: Tucum. Detalhe da parte superior da urna, com dupla carena e frisos em greca e uma banda com linhas largas onduladas, desenhadas em preto e recheadas em vermelho. Esse motivo e o formato das carenas duplicadas são inéditas nos recipientes Tupi na Bahia. 


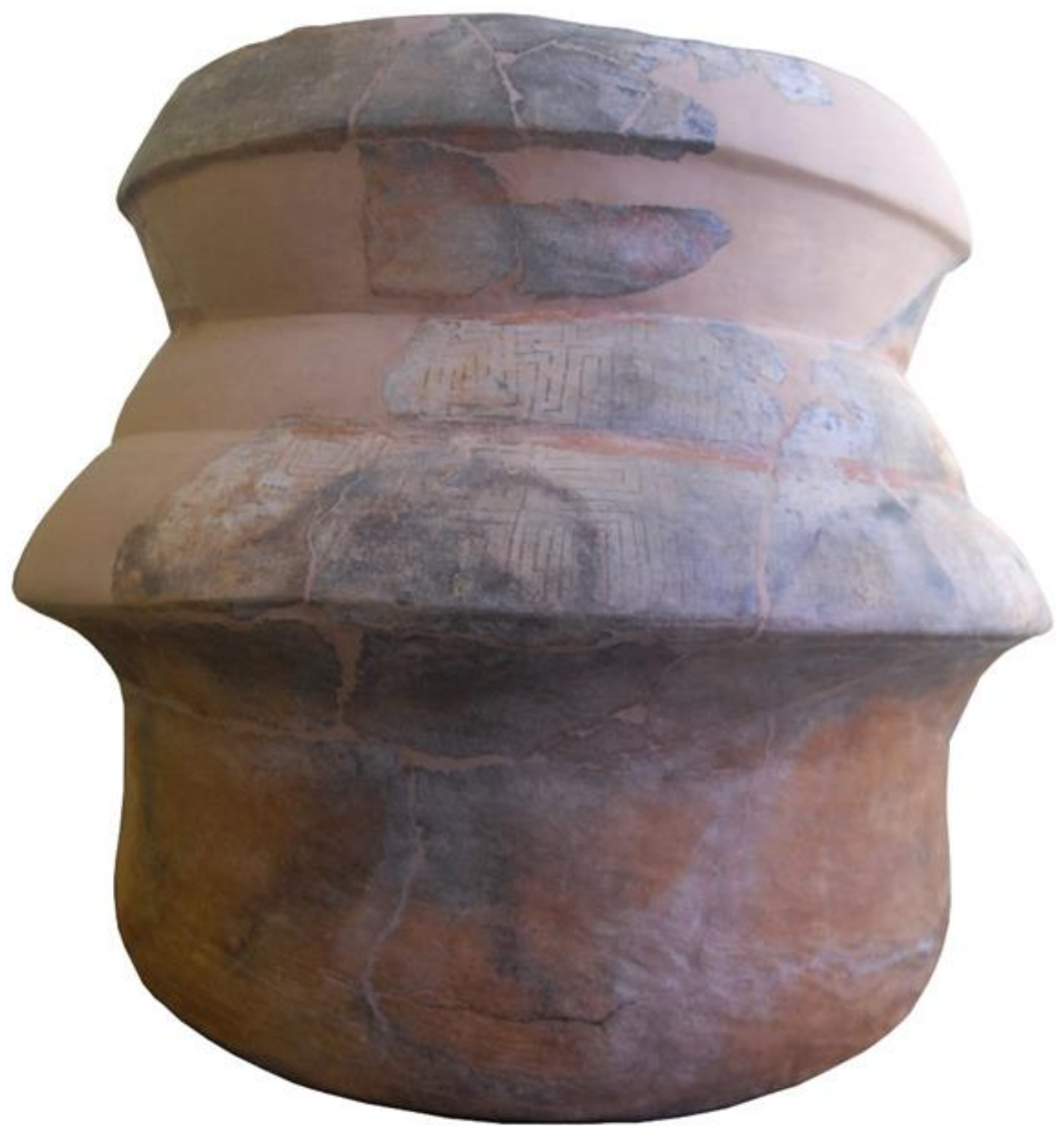

Figura 15: Tucum. Urna restaurada por Fernando Santana, no Laboratório de Arqueologia da $\mathrm{FFCH} / \mathrm{UFBA}$.

\section{Referência}

ALBUQUERQUE, M. 2008. Recipientes cerâmicos Tupi, no Nordeste brasileiro. Os ceramistas Tupiguarani (Org. André Prous e Tania A. Lima). Vol. 1. Sigma, Belo Horizonte.

ETCHEVARNE, C. 2009. Os grupos Tupi na Bahia: uma abordagem arqueológica. Estado da arte das pesquisas arqueológicas sobre a Tradição Tupiguarani (org. Ana Paula de Oliveira) EDUF, Juiz de Fora.

ETCHEVARNE, C. 2020. A história da Bahia, antes da colonização portuguesa. Revista Nordestina de História do Brasil (v. 2, n. 4) UFRB, Cachoeira.

https://pt.wikipedia.org/wiki/Tanha\%C3\%A7u\#/media/Ficheiro:Bahia_Municip_Tanhacu.svg 
Presença Tupi em Tucum, Município de Tanhaçu, Bahia: Urna Funerária e Outros Materiais Arqueológicos

MARTIN, G. 1996. Pré-história do Nordeste do Brasil. UFPE. Recife.

OLIVEIRA, C. 2009. As fronteiras tecnológicas de grupos pré-históricos ceramistas do Nordeste. Estado da Estado da arte das pesquisas arqueológicas sobre a Tradição Tupiguarani (org. Ana Paula de Oliveira) EDUF, Juiz de Fora. 